\title{
On the Diversity and Influence of the Eusebian Alliance: The Case of Theodore of Heraclea
}

\author{
by MATTHEW R. CRAWFORD \\ University of Durham \\ E-mail: m.r.crawford@durham.ac.uk
}

This article offers, for the first time in English, a reconstruction of the career of Theodore of Heraclea, a leading figure in the Eusebian alliance from the early 33 os until the mid-350s. It also provides an overview of Theodore's literary remains and suggests that the antiMarcellan tone of his surviving fragments is in keeping with the other documents that emanated from the Eusebian alliance during this period, especially those from the Council of Serdica (343) and the Council of Sirmium (35I). Finally, it is suggested that the diversity of ways in which Theodore was received by later patristic authors illustrates that the polarising categories of 'Arian' and 'Nicene' are insufficiently nuanced to describe Theodore's actual theological concerns.

\footnotetext{
s scholarship on the fourth-century 'Arian' conflict continues to grow, one feature of the period that is becoming increasingly clear 1 is the diversity that existed on both sides. The terms 'Arian' and 'Nicene' have long since been shown to be insufficient descriptors for the varied figures who made up the opposing sides in this conflict. Moreover, using such terms casts the debate as primarily a theological one, ignoring

CSEL $=$ Corpus scriptorum ecclesiasticorum latinorum; EOMIA $=$ C. H. Turner, Ecclesiae occidentalis monumenta iuris antiquissima, Oxford 1930; GCS = Die griechischen christlichen Schriftsteller der ersten drei Jahrhunderte; HE = Historia ecclesiastica; $\mathrm{SC}=$ Sources Chrétiennes

I would like to thank Lewis Ayres and Mark DelCogliano for their comments on earlier versions of this article.
} 
the variety of other motivations and accusations driving events forward through the tumultuous years following the Council of Nicaea in 325. The polarising categories of 'Nicene' and 'Arian' are largely a tendentious construct of Athanasius himself, created to help his own cause, and fail to do justice to the diversity that existed in the opposing parties. ${ }^{1}$ Yet it was this polarising narrative that fifth-century ecclesiastical historians inherited and made their own, and thus passed on to the Christian Church for the greater part of its existence. Recent studies have sought to deconstruct this Athanasian narrative in order to shed further light on the all-important years between Nicaea in 325 and Constantinople in 381 .

The aim of this article is to continue this project of deconstruction through a consideration of Theodore of Heraclea, an important, but hitherto ignored, non-Nicene figure. The recent study of the Eusebians by David Gwynn, while noting Theodore's involvement in the alliance, fails to take account of his literary remains, and yet, as Gwynn points out, 'it is precisely because they are subordinated to Athanasius' collective construction of an "Arian party" that it is essential to identify and to study the socalled "Eusebians" as individuals in their own right'. ${ }^{2}$ The present study is an attempt to do just that. Theodore has been somewhat better served in German scholarship on the period, with two journal articles published that deal with his significance, but these have been largely ignored in English scholarship on the period, and are now somewhat dated. 3 Thus, in this

${ }^{1}$ So David M. Gwynn, The Eusebians: the polemic of Athanasius of Alexandria and the construction of the 'Arian controversy', Oxford 2007, 6.

${ }^{2}$ Ibid. 115 . Later (p. 122) he writes, 'No evidence even of this fragmentary quality illuminates the individual theological positions of Maris of Chalcedon, Patrophilus of Scythopolis, or Theodore of Heraclea. All three were prominent members of a number of eastern councils in the years following $325, \ldots$ but no personal statements attributed to any of these three men survive'. Pace Gwynn, there are hundreds of extant fragments from Theodore, a sampling of which are considered at pp. $24^{6-} 5^{1}$ below.

3 The only studies of Theodore's life and work that I am aware of are Knut Schäferdiek, "Die Fragmente der "Skeireins" und der Johanneskommentar des Theodor von Herakleia', Zeitschrift für deutsches Altertum und deutsche Literatur cx (1981), 175-93, and 'Theodor von Herakleia (328/34-351/55): ein wenig beachteter Kirchenpolitiker und Exeget des 4. Jhs.', in Gerhard Wirth, Karl-Heinz Schwarte and Johannes Heinrichs (eds), Romanitas-Christianitas: Untersuchungen zur Geschichte und Literatur der römischen Kaiserzeit, Berlin 1982, 393-410. Both are reprinted in Knut Schäferdiek, Winrich Alfried Löhr and Hans Christof Brennecke (eds), Schwellenzeit: Beiträge zur Geschichte des Christentums in Spätantike und Frühmittelalter, Berlin 1996. See also the brief introductions to Theodore in Joseph Reuss, Matthäus-Kommentare aus der griechischen Kirche, Berlin 1957, pp. xxvi-xxix; Johannes-Kommentare aus der griechischen Kirche, Berlin 1966, pp. xx-xxiii; and Lukas-Kommentare aus der griechischen Kirche, Berlin 1984, p. xxii; Robert Devreesse, Les Anciens Commentateurs grecs des Psaumes, Rome 1970, 328; M.-J. Rondeau, Les Commentaires patristiques du Psautier: (IIIe-Ve siècles), Rome 1982, i. 75-6; and Anastasia Moraitis, 'Theodoros, Bischof von Herakleia', in Biographischbibliographisches Kirchenlexikon, xxiv, Herzberg 2005, 1479-85. Gustave Bardy's classic study, Recherches sur saint Lucien d'Antioche et son école, Paris 1936, only mentions 
article is offered for the first time in English a reconstruction of Theodore's career, a survey of his surviving works, and an overview of his reception in the decades following his death. It is argued that Theodore was a leading figure of the Eusebian alliance from the early 33 os until the mid-35os; that his extant works demonstrate a concern to oppose Marcellus and probably also link Marcellus to Montanism; and that later pro-Nicene authors responded to Theodore with both censure and praise, which suggests that the categories of 'Arian' and 'Nicene' were as insufficient for fifth-century writers as they are today.

\section{The career of Theodore of Heraclea}

Theodore's name occurs frequently in the literature from the fourth century, and he is always associated with those around Eusebius of Nicomedia, who together with Eusebius of Caesarea formed the centre of the so-called Eusebian alliance. 4 Occasionally the ancient sources refer to him simply as 'Theodore', without specifying his see, though in such cases it is fairly certain that it is Theodore of Heraclea who is being referred to, since no other Theodore appears to have been involved in the conflict at this stage. He is variously described as 'the Thracian', 'of Heraclea' and 'of Perinthus'. Sozomen explains this variation with his statement that Heraclea was previously known as Perinthus.5 The city was on the Marmara Sea, about ninety-five kilometres west of Constantinople and, prior to the establishment of the imperial capital, its bishop presided over the bishop of Byzantium. ${ }^{6}$ Today it is a small town, known as Marmara Ereğlisi.

Despite the claim of Gelasius Cyzicus that Theodore was present at Nicaea and supported the opinion of Arius, he most likely did not attend that council, since the lists of participants include Paideros of Heraclea, who was presumably Theodore's predecessor and was later counted by Athanasius as one of his supporters. 7 The first reliable date that can be

Theodore in passing. As noted in Gwynn, The Eusebians, 204 n. 99, Philostorgius does not include Theodore among the 'Lucianist party' in his $H E$ ii.3.

4 The term 'alliance' is used deliberately here rather than 'party', following recent scholarship that has shown the theological diversity within the so-called 'church parties' of this period: Gwynn, The Eusebians, p. vii; Mark DelCogliano, 'The Eusebian alliance: the case of Theodotus of Laodicea', Zeitschrift für antikes Christentum xii (2008), 250-66; Lewis Ayres, Nicaea and its legacy: an approach to fourth-century Trinitarian theology, Oxford 2004, 52; and Joseph T. Lienhard, Contra Marcellum: Marcellus of Ancyra and fourthcentury theology, Washington, DC 1999, 34f.

5 Sozomen, HE iii.5.10, in Sozomenus Kirchengeschichte, ed. Joseph Bidez and Günther Christian Hansen, GCS, Berlin 1960, 107. ${ }_{6}^{6}$ Schäferdiek, 'Die Fragmente', 187.

7 So idem, 'Theodor von Herakleia', 393; Gelazius of Cyzicus, HE ii.7.43, in Gelasius Kirchengeschichte, ed. Gerhard Loeschcke and Margret Heinemann, GCS, 
given for Theodore is 334, at which time, according to Theodoret, he acted with Eusebius of Nicomedia and Theognis to bring charges against Athanasius before Constantine, on account of which the emperor attempted to convene a council at Caesarea. ${ }^{8}$ Athanasius later listed him as one of those bishops who were brought into office by Eusebius for the purpose of promoting the Arian heresy, and, since this presupposes the restoration of Eusebius in 327 or 328 , his elevation as a bishop must have occurred sometime between 327 and $334 .{ }^{9}$ It cannot be entirely ruled out that he actually did attend Nicaea as an aide to Paideros his bishop, but as the only evidence for this is the claim of Gelasius, it seems unlikely.

When Athanasius refused the imperial summons to appear before a council at Caesarea, Constantine commanded him to come to Tyre to answer the charges being levied against him, and Theodore is again found playing a central role in the events surrounding the Council of Tyre in 335 . He not only attended the council, but was recognised by Athanasius' Egyptian supporters as one of the leading 'conspirators' who were seeking his demise, alongside Eusebius, Theognis, Maris, Narcissus and Patrophilus. ${ }^{10}$ Furthermore, Theodore was a member of the delegation sent to Mareotis in Egypt to investigate the complaints brought against Athanasius by the Melitians. ${ }^{11}$ Along with Theodore, the other members of the Mareotic commission were Theognis, Maris, Macedonius, Ursacius

Leipzig 1918, 54; and Athanasius, Epistula ad episcopos Aegypti et Libyae 8.4, in Athanasius Werke i/1, ed. Karin Metzler, Berlin 1996, 48. Paideros's name shows up in the Latin, Greek, Syriac, Arabic and Armenian lists of the council attendees: Heinrich Gelzer, Heinrich Hilgenfeld and Otto Cuntz, Patrum Nicaenorum nomina, Stuttgart-Leipzig 1995 , i. 202 ; ii. 201 ; iii. 201 ; iv. 187 ; v. 197; viii. 203 ; ix. 206; x. 16 ; xi. 196.

Theodoret, HE i.28.2, in Theodoret Kirchengeschichte, ed. Léon Parmentier and Günther Christian Hansen, GCS, Berlin 1998, 82; Sozomen, HE, ii.25.1; cf. Schäferdiek, 'Theodor von Herakleia', 393-4, and Timothy D. Barnes, Athanasius and Constantius: theology and politics in the Constantinian empire, Cambridge 1993, 21.

9 Athanasius, Epistula ad episcopos Aegypti et Libyae 7.4 (Metzler, 46); cf. Schäferdiek, 'Theodor von Herakleia', 394. Athanasius also included in this list George of Laodicea, Leontius, Stephanus, Ursacius, Valens, Acasius, Patrophilus, Narcissus and others. On the dating of Eusebius' restoration see Barnes, Athanasius and Constantius, 17-18.

${ }^{10}$ Letter from the Egyptian bishops to the bishops gathered at Tyre, preserved in Athanasius, Apologia contra Arianos 77.2, in Athanasius Werke, ed. Hans-Georg Opitz, ii/ 1, Berlin 1938, 156; cf. Schäferdiek, 'Theodor von Herakleia', 394; Gwynn, The Eusebians, 82-7; Sara Parvis, Marcellus of Ancyra and the lost years of the Arian controversy, 325-345, Oxford 2006, 125; and Barnes, Athanasius and Constantius, 22-3. Gwynn points out that this is the first time in the ancient literature that the accusations against Athanasius are dismissed as the product of a 'heretical conspiracy', and that the polarising narrative of the 'Eusebians' versus the orthodox originates in the context of this council.

${ }^{11}$ Sozomen, HE ii.25.19 (Bidez and Hansen, 87); cf. Socrates, HE i.31.3, in Sokrates Kirchengeschichte, ed. Günther Christian Hansen and Manja Sirinjan, GCS, Berlin 1995 , 81; Theodoret, HE i.3o.1 1 (Parmentier and Hansen, 87); and Athanasius, Apologia contra Arianos 75.1 (Opitz, 154). See also Schäferdiek, 'Theodor von Herakleia', 395, and Barnes, Athanasius and Constantius, 22. 
and Valens. Theognis's name occurs first in the list of the members of the commission, which suggests he was probably recognised as its leader. The Egyptian bishops charged that these delegates were biased against Athanasius, an accusation probably arising from the involvement of Theodore and Theognis in the campaign against him in the previous year. Hanson's assessment that these were 'anti-Athanasian' or perhaps more accurately 'pro-Eusebian' bishops is the best description for the commission. ${ }^{12}$ It was on the basis of their report that the council condemned Athanasius in the summer of 335 and forbade him to return to his see.

When Athanasius then fled to Constantinople, several members of the Eusebian alliance travelled to the imperial court as witnesses to defend the council's condemnation of him. The sources are agreed that at least three members of the Mareotic commission made this trip - Theognis, Ursacius and Valens. Moreover, in Sozomen's account Theodore is included among those who appeared before the emperor, though he is left out of Athanasius' list. ${ }^{13}$ Given his participation in the Mareotic commission, and the close proximity of his see to the imperial capital, it is reasonable to suppose that he joined those who approached Constantine. Upon hearing their report, Constantine banished Athanasius to Gaul. Thus, for his role in the events of 334-5 Theodore deserves to be ranked among the half-dozen or so people most directly responsible for Athanasius' first exile.

Theodore next appears at the synod that deposed Marcellus in July $33^{6 .}$ Although no explicit mention of him is made, Eusebius of Caesarea lists the bishop of Thrace as one of those who attended, almost certainly referring to Theodore. $^{14}$ Theodore's presence at this synod in $33^{6}$, as well as participation in the Mareotic commission signals his growing leadership role within the Eusebian alliance, and two features become apparent at this point that were to be constants throughout his career. He is opposed to Athanasius on the basis of the charges brought at Tyre, and he stands against Marcellus on the basis of his supposedly errant theology. Theodore's career over the next two decades will prove to be a workingout of these two impulses against the bishops of Alexandria and Ancyra.

12 R.P.C. Hanson, The search for the Christian doctrine of God: the Arian controversy 3I8-38I, Edinburgh 1988, 260; cf. Barnes, Athanasius and Constantius, 22-3.

13 Sozomen, HE ii.28.13 (Bidez and Hansen, 93); Athanasius, Apologia contra Arianos 87.1 (Opitz, 165-6). Athanasius also included the two Eusebii and Patrophilus, while Socrates adds Maris and removes Eusebius of Caesarea (HE i.35.1-2); cf. Schäferdiek, 'Theodor von Herakleia', 395. Barnes and Gwynn do not include Theodore in the delegation: Athanasius and Constantius, 23; The Eusebians, 109-10.

${ }^{14}$ Eusebius, Contra Marcellum ii.4.29, in Eusebius Werke IV, ed. Erich Klostermann, GCS, Leipzig 1906, 58. So Parvis, Marcellus of Ancyra, 1 29; cf. Sozomen, HE ii.33.1-4. I follow Barnes's dating of this event to 336: Athanasius and Constantius, $5^{6}$. The council also declared Arius to be orthodox and appointed Basil as Marcellus' replacement. 
Paul of Constantinople is the third opposing figure who looms large in the story of Theodore's episcopal career. When Constantine died on 22 May 337, Athanasius and all the other exiled bishops were allowed to return to their sees. During the summer of 337 , while on his way back to Alexandria, Athanasius stopped in Constantinople and while there likely participated in the consecration of Paul as the new bishop of Constantinople in sucession to Alexander. According to Sozomen, Theodore along with Eusebius contested the consecration of Paul, since they held that the right of ordination resided with them as the nearest bishops to the capital city, while in fact they had been entirely left out of the process. ${ }^{15}$ Their prior opposition to Athanasius undoubtedly played a role in their resistance to Paul whose tenure proved to be a short one, for by autumn of the same year, Constantius, who now ruled in the East, ordered that his election be overturned. Thus, Theodore, along with Maris, Theognis, Menophantus, Ursacius and Valens, gathered at Constantius' request to depose Paul and replace him with Eusebius. ${ }^{16}$ These events demonstrate Theodore's involvement at a key juncture in the Eusebian alliance as Athanasius' attempt to extend his influence to the imperial capital was thwarted and Eusebius was elevated to the see of Constantinople.

In the winter of $337 / 8$, a council met, probably in Antioch, to depose Athanasius and install a successor, and it announced its decision by sending letters to Constantius and Julius of Rome. The Egyptian synod that met in response to this attack on Athanasius did not specify any of the attendees at the council, but its letter mentions Eusebius and those with him who are bringing charges against Athanasius. ${ }^{17}$ Since by this point Theodore was clearly a close associate of Eusebius, it is reasonable to suppose that he attended the Antiochene council. The attempt to depose Athanasius proved unsuccessful, but his enemies were undeterred. According to Theodoret, sometime after Athanasius had been restored in 337, Theodore, Eusebius and Theognis, through the medium of a certain unnamed 'Arian' priest, convinced Constantius that it was the introduction of the unscriptural term ónoov́øioৎ into the creed that had caused such controversy. These bishops frequently visited the emperor since they lived

${ }^{15}$ Sozomen, HE iii.3.1 (Bidez and Hansen, 104); cf. Schäferdiek, 'Theodor von Herakleia', 394, who does not give an exact date for this event. On the chronology see Hanson, The search, 265 n. 106, and Barnes, Athanasius and Constantius, $212-13$. Here I follow Barnes's dates for Paul's career.

${ }^{16}$ Hilary, Fragmenta historica, ser. B ii.1.2, in S. Hilarii Episcopi Pictaviensis opera IV, ed. A. Feder, CSEL lxv, Leipzig 1916, 106; Socrates, HE ii.7.1-3 (Hansen and Sirinjan, 97); Sozomen, HE iii.4.3 (Bidez and Hansen, 105); cf. Parvis, Marcellus of Ancyra, 147; Barnes, Athanasius and Constantius, $3^{6 .}$

${ }_{17}$ Athanasius, Apologia contra Arianos 3.2. See Barnes's reconstruction of the events in Athanasius and Constantius, 36-40. 
near him, arguing that the return of Athanasius had caused much trouble. ${ }^{18}$

The best date for these events is sometime in 338, after Athanasius had travelled to Constantinople in the spring of that year and been cleared by Constantius of the charges. ${ }^{19}$ Furthermore, Parvis may be correct that Theodore and the others used as evidence against Athanasius the tumultuous nature of his journey through Cappadocia on the way to the capital in $338 .{ }^{\circ \circ}$ As a result of their intrigue, another council was convened in Antioch in the winter of 338/9, which deposed Athanasius and appointed Gregory as his replacement. ${ }^{21}$ Thus began Athanasius' second exile. Though there is no surviving record of who attended this council, it is likely that Theodore would have played a part, since he was involved in bringing the charges before the emperor in 338. If Timothy Barnes is correct that this council also deposed Marcellus after his return from exile, and reinstalled Basil in his place, then the years between the Council of Tyre in 335 and the Dedication Council in 341 find Theodore consistently on the side opposing Athanasius, Marcellus and Paul, being integrally involved in the deposition of all three on repeated occasions. ${ }^{22}$ Though not the central figure of the Eusebian alliance during these years, he was clearly an influential and visible person, as evidenced by the proximity of his see to the imperial capital and his continued involvement in ecclesiastical politics.

\section{The Dedication Council of Antioch and its aftermath}

Athanasius fled to Rome seeking refuge from Julius, where he joined his fellow exile Marcellus. The bishop of Rome eventually took up their cause and wrote to the eastern bishops proposing a joint council in Rome presided over by himself to settle the dispute. In January $34^{1}$ the eastern bishops met in Antioch at the so-called 'Dedication Council' in order to consider Julius' letter. Of the ninety-seven participants, Sozomen listed eight that must have been leading lights at this council, and included among this number is Theodore. ${ }^{23}$ The council, with Constantius present,

18 Theodoret, HE ii.3.8 (Parmentier and Hansen, 97).

19 For the evidence of Athanasius' journey through Cappadocia and audience before Constantius see Barnes, Athanasius and Constantius, 41-5.

${ }^{20}$ Parvis, Marcellus of Ancyra, $14^{1-2 .}$

${ }^{21}$ Socrates, HE ii.8.6; cf. Barnes, Athanasius and Constantius, 45-6, who asserts (pp. 201, $25^{2}$ n. 44) that Socrates confuses this council with the Dedication Council of Antioch in 341. $\quad{ }^{22}$ Barnes, Athanasius and Constantius, 57.

${ }^{23}$ Sozomen, HE iii.5.10 (Bidez and Hansen, 107); Athanasius, Apologia contra Arianos 21.1 (Opitz, 102). The number of bishops present is mentioned in Sozomen, $H E$ iv.22.22, and Hilary, De synodis 28, PL x.502; cf. Schäferdiek, 'Theodor von Herakleia', 396; Gwynn, The Eusebians, 220-9; and Parvis, Marcellus of Ancyra, 162-3. The sequence 
produced three creedal formulae, and another gathering in the summer of $34^{2}$ produced a fourth. Along with the fragments of his works that are extant and the letter of the eastern bishops from the Council of Serdica, these formulae are one of the best sources for determining Theodore's own theological position. The anti-Sabellian, or more precisely antiMarcellan, tone of the Antiochene formulae coincides well with the explicitly anti-Sabellian stance of Theodore's fragments from the catenae. ${ }^{24}$ Although Athanasius and the fifth-century ecclesiastical historians viewed the second Antiochene creed as 'Arian', Hilary of Poitiers more perceptively treated it as pro-Nicene, and recognised that it was intended primarily to oppose modalism. ${ }^{25}$

Two priests from Rome then took the council's decision to Julius, who responded by holding his own council despite the absence of the easterners. The fifty or so bishops who attended this council exonerated Athanasius and criticised the way in which the Mareotic commission had handled the charges brought against him. Julius then wrote back to the Eusebian bishops in Antioch and included Theodore of Heraclea again as a leader in the alliance of Eusebius of Nicomedia, among also Dianius, Flacillus, Eusebius, Maris and Macedonius. ${ }^{26}$ Julius probably mentioned Theodore both because he had been a member of the Mareotic commission, whose findings were in dispute, and because he had held a leading position at the Dedication Council.

Thus, the Dedication Council and its aftermath testify to Theodore's continued opposition to Athanasius, as a result of which he is now brought into open conflict with the bishops in the west, most notably Julius of Rome. Moreover, the characterisation of this conflict as a battle between the Eusebians and the orthodox is no longer confined to the writings of the Egyptian bishops at Tyre, but is specifically endorsed by Julius and the western bishops. Theodore is viewed by those in the west as clearly on the side of the Eusebians, although at this point in the conflict Julius does not go as far as to describe the members of the Eusebian alliance as 'Arians'. ${ }^{27}$

of events here is complicated. I am following the reconstruction in Barnes, Athanasius and Constantius, 56-62, which differs from Hanson, The search, 274-93, who has Julius' letter preceding the Dedication Council. See Barnes's comment at pp. $255^{-6}$ n. 11 .

${ }^{24}$ On the anti-Sabellian nature of these formulae see Ayres, Nicaea and its legacy, 117-22; Lienhard, Contra Marcellum, 167-72; and Hanson, The search, 285-92. For Theodore's anti-Sabellian fragments see pp. 247-8 below.

${ }^{25}$ So Ayres, Nicaea and its legacy, 121 . See Hilary, De synodis 32-3, and Sozomen's discussion and puzzlement at the document in $H E$ iii.5.6-8. On the second creed of Antioch see also Gwynn, The Eusebians, 220-9.

${ }_{26}$ This is preserved in Athanasius, Apologia contra Arianos 2 1.1-35.8 (Opitz, 102-13); cf. Hanson, The search, 270, and Schäferdiek, 'Theodor von Herakleia', 396.

${ }^{27}$ So Gwynn, The Eusebians, 89-94, who interprets the letter as evidence of Athanasius' tendentious account influencing Julius. 
Sometime in $34^{1}$ or $34^{2}$ Eusebius died, and Paul attempted to regain the see that he had lost in 337. Opposing him were nearby Eusebian bishops, Theognis of Nicaea, Maris of Chalcedon and Theodore of Heraclea, as well as Ursacius and Valens. Paul was successfully installed by the people, but again did not last long. ${ }^{28}$ After a mob in the city lynched the general Hermogenes who had been sent by Constantius to depose Paul, the emperor himself came to the city to remove the new bishop and punish the people. The Historia acephala reports that, although Theodore and his associates then sought to insert Eudoxius into the leadership vacuum in the capital city, the people began to riot, apparently out of loyalty to Paul, forcing the bishops to ordain instead Macedonius, who had been a priest under Paul. ${ }^{29}$

Meanwhile Paul fled to the western imperial court at Trier, prompting Constans to take up the cause of the eastern bishops who were now in exile. The western emperor thus wrote to his brother in the east requesting a delegation to justify the condemnation of Athanasius and Paul. In response, Constantius sent a delegation of four bishops to Trier in the autumn of $34^{2}$, carrying with them the Fourth Creed of Antioch. $3^{\circ}$ The members of the delegation were Narcissus of Neronias, Maris of Chalcedon, Mark of Arethusa and Theodore..$^{11}$ Theodore's involvement in the mission is in keeping with the delegation's intentions. He had been involved in the Mareotic commission and had also opposed both of Paul's attempts to secure the bishop's seat in the capital, and so was well suited to speak to the charges against both men. Maris had also served on the

${ }^{28}$ Socrates, HE ii.1 2.3 (Hansen and Sirinjan, 103); cf. Sozomen, HE iii.7.4 (Bidez and Hansen, 109) who mentions only Theodore and Theognis by name, but says that there were several others with them in this attempt; cf. Schäferdiek, 'Theodor von Herakleia', 396-7; Parvis, Marcellus of Ancyra, 204.

${ }^{29}$ Historia acephala 1.4-5, in Annik Martin and Micheline Albert, Histoire 'Acéphale' et index syriaque des lettres festales d'Athanase d'Alexandrie, SC cccxvii, Paris 1985, 140; cf. Barnes, Athanasius and Constantius, 68-9. Barnes points out that this passage of the Historia acephala is 'horribly confused', and he dates the reference to Theodore's attempt to ordain Eudoxius to 359/6o (p. 217). However, if Theodore was dead by 355 , as seems likely, then the text is probably referring to the events of $34^{2}$, unless the assertion of Theodore's involvement is simply incorrect.

$3^{\circ}$ The creed can be found in Athanasius, De synodis 25.2-5, in Athanasius Werke ii/ 1 , ed. Hans-Georg Opitz, Berlin 1940, 251, and Socrates, HE ii.18.3-6 (Hansen and Sirinjan, 1 1 1-12). Athanasius says that the creed was formed by a second gathering of bishops while Socrates and Sozomen suggest that the ambassadors to Trier created the formula en route. Barnes follows Athanasius' account and argues that it was produced by a second gathering of bishops in the summer of 342: Athanasius and Constantius, 230. So also Ayres, Nicaea and its legacy, 121 , and Gwynn, The Eusebians, 221.

${ }^{11}$ Socrates, $H E$ ii.18.1 (Hansen and Sirinjan, 111 ). See also Athanasius, De synodis 25.1 (Opitz, 250-1), and Sozomen, HE iii.10.4 (Bidez and Hansen, 113 ), though the latter does not mention Maris as among the participants in the delegation; cf. Hanson, The search, 284, 293; Schäferdiek, 'Theodor von Herakleia', 397; and Parvis, Marcellus of Ancyra, 206-10. 
Mareotic commission and in the attempts to oppose Paul, so it should not be assumed that Theodore was the sole leader of the delegation. However, his involvement signals his continuing role as one of a handful of leading figures. $3^{2}$

\section{The débâcle at Serdica}

As Timothy Barnes observes, the outcome of the delegation to Trier is unknown, but only a short while later Constans wrote to Constantius to insist on a council that would bring together both sides in the conflict.33 Presumably Theodore headed back east before being summoned, along with the other easterners, to the resulting Council of Serdica that met in the late summer of $343^{34}$ In the débâcle that followed, Theodore assumed his most prominent position yet in the Eusebian alliance, and it is at this point that his influence in the controversy appears to have peaked. When the Eusebians refused to meet the western bishops, the council met anyway and produced several conciliar documents, most of which put Theodore in a significant position. Of the eight documents coming out of the western council of Serdica, six mention Theodore among the list of deposed Eusebians, and five of those put him at the top of the list.

The most important document to emerge from the western council, the Synodical letter to all churches,35 first refers to the Eusebians who had previously written to Julius against Athanasius and Marcellus, and includes in the list Maris, Theodore, Theognis, Ursacius, Valens, Menophantus and Stephen. $3^{6}$ However, when the letter comes later to address the current 'leaders' ('̌ $\xi \rho \chi 0 \mathrm{o})$ of the Eusebians who have gathered at Serdica, Maris is no longer mentioned, and Theodore is at the head of the list, followed by Narcissus, Stephen, George, Acacius, Menophantus, Ursacius and Valens. 37 By promoting those who have been cast out for holding the 'Arian heresy',

$3^{2}$ So Schäferdiek, 'Theodor von Herakleia', 398-9, who notes that Narcissus was also clearly a leader of the alliance at this time.

33 Barnes, Athanasius and Constantius, 69. Athanasius refers to the letter of Constans to Constantius in the Apologia ad Constantium $4 \cdot 4$.

34 On the Council of Serdica see Hanson, The search, 293-3o6; Parvis, Marcellus of Ancyra, 218-22; and Barnes, Athanasius and Constantius, 71-81. On the limitations of the terms 'western' and 'eastern' as descriptors for the opposing sides of the council see Ayres, Nicaea and its legacy, 123. The terms are used here for the sake of convenience. On the date of the council see Barnes, Athanasius and Constantius, 71.

35 This is preserved in Theodoret, HE ii.8.1-52 (Parmentier and Hansen, 101-18). See also the Latin version in Hilary, Fragmenta historica, ser. B ii.1.1-8 (Feder, 103-26). Sozomen also lists Theodore first in the list of deposed eastern bishops: HE iii.1 2.3 (Bidez and Hansen, 1 16); cf. Hanson, The search, 300, and Gwynn, The Eusebians, 111.

$3^{6}$ Theodoret, HE ii.8.6 (Parmentier and Hansen, 102).

37 Ibid. ii.8.28 (Parmentier and Hansen, 109). 
they themselves 'propagate impiety' and 'corrupt the right faith'.$^{8}$ Several lines later, when the letter declares these persons to be excommunicated, Theodore again heads the list of Eusebians. 39

The Synodical letter to the bishops of Egypt and Libya also puts Theodore first, describing him along with the other bishops as the "heads of the Arian heresy'. $4^{\circ}$ The council also composed a Synodical letter to the churches of the Mareotis and, in its list of the deposed, Theodore is again first among those who are 'associates and advocates of the most wicked heresy' ('ob impiissimam heresim cuius socii et patroni videntur'), followed by the same list of names as in the Letter to all churches. $4^{11}$ Athanasius' own Letter from Serdica to the churches of the Mareotis only mentions three of the deposed bishops-Theodore, first again, as well as Ursacius and Valens..$^{2}$ The reason that only these three bishops are named is presumably because the letter is attempting to discredit the report of the Mareotic commission of 335 .

Athanasius also composed a Letter from Serdica to the clergy of Alexandria and the Parembole. Its list of deposed bishops, described as the 'successors of the slanderous heresy of Eusebius', is the same as in the Letter to all churches. 43 Once more, Theodore is first. Furthermore, the Synodical letter to the Emperor Constantius similarly warns against the blasphemy of two Eusebii, Narcissus, Theodore, Stephanus, Acacius, Menophantus, Ursacius and Valens. 44 The only two documents not to name Theodore are the Synodical letter to the church of Alexandria, which does not include a list of the condemned, and simply refers to them generically as 'those around Eusebius' who oppose 'the orthodox'45; and the Synodical letter to Pope Julius, which fails to mention Theodore in its list of heretics, while including Ursacius, Valens, Narcissus, Stephen, Acacius, Menophantus and George. $4^{6}$

The omission of Theodore's name in the Letter to Julius is an odd exception to the otherwise consistent pattern of including him in the list of the Eusebian leaders and usually at the head of the list. The only specific action attributed to Theodore at the council was that he came forward, along with the four other surviving members of the Mareotic commission, to suggest that a new bipartisan commission be sent to Egypt to investigate the charges once more, an idea that found no acceptance

$3^{8}$ Ibid. ii.8.27 (Parmentier and Hansen, 109).

39 Ibid. ii.8.33 (Parmentier and Hansen, 111 ).

$4^{\circ}$ Athanasius, Apologia contra Arianos 40.3 (Opitz, 118); cf. Apologia contra Arianos 36.6 (Opitz, 115 ).

$4^{1}$ EOMIA, 1.2.4 $657 . \quad 4^{2}$ Ibid. 1.2.4, $659 . \quad 43$ Ibid. 1.2.4, 654 .

44 Hilary, Oratio synodi Sardicensis ad Constantium imperatorem 5.2 (Feder, 184); cf. Hanson, The search, 305-6, and Barnes, Athanasius and Constantius, 80-1.

45 Athanasius, Apologia contra Arianos 40.1 (Opitz, 1 18). An allusion might be made to him when Athanasius refers to 'certain most depraved and abominable youths' who created reports in Mareotis: Apologia contra Arianos 37.7 (Opitz, 116 ).

$4^{6}$ Hilary, Fragmenta historica, ser. B ii.2.3 (Feder, 131 ). 
among the westerners. 47 Nevertheless, we can be sure that, at least from the western perspective, Theodore was one of the most prominent leaders of the Eusebian alliance, and perhaps even ranked first among the 'Arian' heretics at this point, since Eusebius had now died. Moreover, there is a shift in the rhetoric evident in these documents. Gwynn is surely correct to see in them the growing influence of Athanasius' account of the conflict, since, while Theodore and the others had previously been lumped together as the Eusebians in the earlier letter from Julius to Antioch, they now are explicitly described as 'Arians' who are corrupting the true faith. $4^{8}$

The Eusebians withdrew to Philippopolis whence they issued the sole document produced by their party at the council. In it the bishops condemned the theology of Marcellus and the misconduct of Athanasius and Paul, and excommunicated the leading westerners. The easterners at Philippopolis also put forth as a profession of faith the fourth formula from Antioch with the addition of a list of anathemas that seem intended to allay western fears of tritheism, while ruling out Sabellianism and Arianism.49 In light of his prominence from the western perspective, it is curious that Theodore is tenth in the list of bishops who subscribed to the document at Philippopolis. $5^{\circ}$ However, the first ten names include several bishops who were relatively minor figures, such as Eulalius and Gerontius, so perhaps no significance should be attached to the ordering of the names.

Theodore's prominence at Serdica could be accounted for by the fact that Eusebius and Theognis had died by this point, and Theodore had already had some dealings with the west in his delegation to Trier in the previous year. $5^{1}$ Maris had also been a part of the delegation to Trier, and was presumably at Serdica as well, but the impression given from the surviving documents is that Theodore took precedence over him..$^{2}$ The fact that the Eusebians would agree to meet with the other party only on condition that the bishops under review (i.e., Marcellus, Athanasius and Paul) should not sit as members of the council is consistent with Theodore's opposition to these three over the previous decade.53 Moreover, the concerns of the encyclical letter issued by the easterners, with its opposition to Marcellus' theology and its assertion of the misconduct of Athanasius and Paul, are also in keeping with Theodore's activities since his first emergence in 334.54

47 Ibid. ser. A iv.1.18 (Feder, 6o).

$4^{8}$ Gwynn, The Eusebians, 94-7.

49 Hilary, Fragmenta historica, ser. A iv.2 (Feder, 69-73); cf. Hanson, The search, 298; Ayres, Nicaea and its legacy, 122-6; and Lienhard, Contra Marcellum, 173-5.

$5^{\circ}$ Hilary, Fragmenta historica, ser. A iv.3 (Feder, 74).

$5^{1}$ Theognis's death is inferred from his absence from the council; cf. Hanson, The search, 296.

$5^{2}$ Hanson includes Maris in the list of eastern bishops: ibid. 295.

53 Hilary, Fragmenta historica, ser. A iv. $1.14^{-1} 5$ (Feder, $5^{8)}$ ). So Barnes, Athanasius and Constantius, 72; cf. Index xv: Martin and Albert, Histoire 'Acéphale', 242-3.

54 Schäferdiek points to the growing role of Theodore during his period: 'Diese Einschätzung der Gegner ist doch wohl ein Hinweis darauf, daß er jetzt zumindest 
After the failed Council of Serdica in 343, there is no indication of Theodore's movements or involvement for the next six years, which does not necessarily imply any diminishing of his role in the Eusebian alliance, but is simply due to the relative lack of documentary evidence. A council met in Antioch in 344 to depose Stephen and to issue the Macrostich creed, but no record of its attendees survives, and Theodore was not among the four bishops chosen to carry the creed westwards. 55 However, the council's opposition to Marcellus and Photinus fits with Theodore's theological concerns and, as a leader of the eastern bishops, there is good reason to suppose that he did attend. $5^{6}$ Perhaps it was during these years that he composed his exegetical works, since he was not so busy attending councils. 57 The fact that Athanasius did not take issue with Theodore in his Orations against the Arians composed in around 340 also suggests that his writings should be placed after this date. $5^{8}$

It is not until early in 349 that Theodore shows up again, when he once more took the lead in having Paul tried and deposed by a council.59 If Barnes is correct in his suggestion that the council was probably not held in Constantinople but somewhere nearby, Theodore's own see of Heraclea has to be regarded as a possible site for the meeting. ${ }^{60}$ Moreover, later the same year he and other Eusebians, around thirty in total, met in Antioch yet again to depose Athanasius who had returned to Alexandria in 346 . Once more Theodore is close to the front of the list of attendees, second only to Narcissus of Cilicia. ${ }^{61}$ The bishops declared Athanasius' return to be against the established rules of the Church, since he had not been reinstated by a council, and they probably also appointed George of Cappadocia in his place, although the decisions of the council were not

zeitweise eine erstrangige kirchenpolitische Führungsposition auszufüllen vermochte': 'Theodor von Herakleia', 399 .

55 Athanasius, De synodis 26.1; cf. Hanson, The search, 309, and Barnes, Athanasius and Constantius, $87-8$.

${ }^{5} 6$ On the theological character of the Macrostich Creed see Ayres, Nicaea and its legacy, $127-9$.

${ }^{57}$ Schäferdiek points out that the theological concerns of Theodore's works best fit the period after Serdica: 'Theodor von Herakleia', 408 .

${ }_{58}^{8}$ In Orations ii.24 Athanasius implies that only Eusebius, Arius and Asterius were writing at this point. So also Barnes, Athanasius and Constantius, 54-5.

59 Historia acephala 1.2 (Martin and Albert, 138); cf. Schäferdiek, 'Theodor von Herakleia', 401, and Barnes, Athanasius and Constantius, 98, 216-1 7 .

60 Barnes, Athanasius and Constantius, 98.

${ }^{61}$ Sozomen, HE iv.8.4 (Bidez and Hansen, 147). The dating of this council is debated. Hanson says that it took place 'in $35^{1}$ (or possibly in 352)': The search, 325 . Parvis gives 349 as a date: Marcellus of Ancyra, 222; and Schäferdiek says 346: 'Theodor von Herakleia', 40o. I am following Barnes who dates it to the autumn of 349 : Athanasius and Constantius, 98. On the date of Athanasius' return to Alexandria see Athanasius and Constantius, 92. 
enforced due to the political changes that quickly followed with the usurpation of Magnentius.

Furthermore, Athanasius suggested that after Ursacius and Valens had agreed to drop the charges against him in 347 , Theodore was one of those who convinced them to come back to their party, a volte-face that Barnes dates to $35^{\mathrm{O} / 1 .}{ }^{62}$ Given the fact that Athanasius made so much of the Illyrian bishops dropping their charges against him, Theodore's apparent involvement in bringing them back to the Eusebian alliance must have been a bitter pill to swallow. ${ }^{6}$

After this point the historical record becomes murkier. Neither Socrates nor Sozomen mention Theodore as present at the Council of Sirmium in $35^{1}$, and Socrates instead lists Theodore's apparent successor, Hypatian of Heraclea, among the attendees, perhaps indicating that Theodore had died by this point. However, both historians confuse this council with the later Council of Sirmium in 357 and do not even agree among themselves on the list of attendees. ${ }^{64}$ In light of these discrepancies, Hanson's caution is probably correct: 'we cannot place much confidence in the lists given us of the members of this Council' ${ }^{65}$ Other evidence, however, does suggest that Theodore was present at Sirmium in $35^{1}$. In one of Liberius' letters, included in Hilary's Collectio antiariana, Theodore is listed among those who, along with Narcissus and the other Eusebians, subscribed to the 'betrayal at Sirmium', probably a reference to Sirmium $35^{1 .}{ }^{66}$ If Theodore did indeed attend the council, which seems likely given Liberius' testimony, the council's decisions were entirely in keeping with his prior activities over the previous decade and a half. First, the council deposed Photinus, associating him with Marcellus. Second, it again put forward the

62 Athanasius, Historia Arianorum 28.1, in Athanasius Werke, ii/1, ed. Hans-Georg Opitz, Berlin 1940, 198); cf. Gwynn, The Eusebians, 112 , and Barnes, Athanasius and Constantius, 97, 99 .

63 See Athanasius, Apologia contra Arianos 88; cf. Barnes, Athanasius and Constantius, 100 .

${ }^{6}$ Socrates, HE ii.29.2 (Hansen and Sirinjan, 140); Sozomen, HE iv.6.4 (Bidez and Hansen, 143-4).

${ }_{5}$ Hanson, The search, 325 n. $5^{2}$. Barnes also notes that Socrates and Sozomen confuse Sirmium $35^{1}$ and Sirmium 357: Athanasius and Constantius, 272-3 n. 1.

66 Hilary, Fragmenta historica, ser. B vii.9 (Feder, 170); cf. Hanson, The search, 359, and Schäferdiek, 'Theodor von Herakleia', 401. The question of which creed is referred to in this statement is a knotty one. Hanson notes that it 'could not represent the bishops who were present at Sirmium 358', and after surveying the evidence for it being either Sirmium $35^{1}$ or Sirmium 357 concludes that the question must be left open: The search, $3_{61-2}$. Barnes sees the list as representing those who attended in $35^{1}$ : Athanasius and Constantius, 273 n. 1. If the report of Theodore's death by 355 is accurate (see p. 242 below), then this suggests that the list of signatories is from Sirmium $35^{1 .}$ 
Dedication creed drawn up in Antioch in 341 and carried from the east to Trier in 342. Third, it again condemned Athanasius. ${ }^{67}$

Thus, his presence at Sirmium underscores once more Theodore's opposition to Marcellus on account of his Monarchianism, and to Athanasius, presumably on the basis of the charges that he had personally investigated in Mareotis in 335. Moreover, the creed issued by the council added a list of anathemas which condemn the use of some ousia language, seemingly directed against those with Marcellan tendencies, but also hinting at the emerging anti-Nicene theologies that became more clearly defined in the following decade. The creed of Sirmium $35^{1}$ is the only statement associated with Theodore that might be taken to indicate that he held to a distinctly anti-Nicene theology, and the creed is more clearly antiMarcellan than anti-Nicene. For this reason Theodore should not be forced into the mould of later anti-Nicenes who more explicitly rejected the creed of 325 . Had he been present at Sirmium in 357 , which directly opposed Nicaea and the homoousios, we would have clearer grounds for attributing anti-Nicene tendencies to him. ${ }^{68}$ However, as it stands, there is no reason to suppose that his continued opposition to Athanasius was based on anything other than the charges brought at Tyre, and therefore had little to do with a theological opposition to the Nicene Creed. The one theological concern that does clearly emerge from Theodore's ecclesiastical career is his attempt to oppose Marcellus' Sabellianism, but it should not be assumed that being anti-Marcellan in these years meant being antiNicene in the sense of the more clearly defined anti-Nicene theologies of the later $35^{\text {os }}$ and beyond. Nicaea itself was to become a matter of debate only in the years after Theodore's passing from the scene.

\section{The date of Theodore's death}

His presence at Sirmium in $35^{1}$ is the last solid date that can be given for Theodore. It is possible that he attended the Council of Arles in 353, which reiterated the decisions of Sirmium. Although no full list of attendees is extant, those who were present were predominantly eastern, and Athanasius later included Theodore in a list of his opponents which Barnes describes as an 'unmistakable allusion' to the Councils of Arles in $353 / 4$ and Milan in $355 .{ }^{69}$ At any rate, the historical evidence suggests that

\footnotetext{
67 Barnes, Athanasius and Constantius, 109. That Athanasius was condemned at this council is nowhere explicitly stated, but see the evidence that Barnes marshals for it at $\mathrm{pp}_{68}{ }^{109-10 .}$

68 On the theological character of the creeds from Sirmium $35^{1}$ and 357 see Ayres, Nicaea and its legacy, 133-40.

69 Athanasius, Epistula ad episcopos Aegypti et Libyae 6-7; Barnes, Athanasius and Constantius, $115,123$.
} 
he died some time prior to 355 . In the autumn of that year, Liberius, bishop of Rome, was arrested and brought before Constantius in Milan on account of his refusal to subscribe to the decisions of Sirmium 351, which had been reaffirmed at the Council of Milan. Theodoret preserves what purports to be an actual transcript of the bishop's interview with the emperor and, during the proceedings, Liberius informed Constantius that Theodore, one of the five who decades earlier had sailed to Mareotis, was now dead. $7^{\circ}$

However, we have to reckon also with three separate reports that have Theodore living beyond this point. First, Athanasius mentioned him in his Encyclical letter to the bishops of Egypt and Libya, composed as he went into exile in $35^{6}$, though he did not say whether he was still alive at this point. ${ }^{71}$ Barnes points out that others mentioned by Athanasius in the letter were already dead as well, so it cannot be assumed, based on this letter, that Theodore was still alive in $35^{6.7^{2}}$ The second report comes from the Historia acephala. According to this account, as Athanasius was making his way from Antioch to Alexandria, Lucius and other 'Arians' approached the emperor Jovian with complaints against him. Those who had taken counsel and appointed Lucius to this task were Eudoxius, Theodore, Sophronius, Euzoius and Hilarius.73 The text simply mentions 'Theodore' without adding 'Heraclea' or 'Perinthus', but no other Theodore appears active during this period who could have been involved in such an attempt. The third report comes from Philostorgius' Ecclesiastical history, preserved in a synopsis created by Photius in the ninth century. According to his account, in 367 or 368 Theodore had a special hand in the consecration of Demophilus, the last Arian bishop of Constantinople before the reign of Theodosius.74 However, Philostorgius (or perhaps Photius) appears to

$7^{\circ}$ Theodoret, HE ii.16.10-11 (Parmentier and Hansen, 132-3). Liberius says that another of the five, Theognis, had also died, and that the other three, Maris, Valens and Ursacius were alive but had since sent a petition for pardon to the council; cf. Schäferdiek, 'Theodor von Herakleia', 401-2. On the interview between Liberius and Constantius see Johannes Herrmann, 'Ein Streitgespräch mit verfahrensrechtlichen Argumenten zwischen Kaiser Konstantius und Bischof Liberius', in Festschrift Hans Liermann zum 7o. Geburtstag, Erlangen 1964, 77-86. Barnes notes that a copy of the dialogue is also extant in Syriac, and that Sozomen ( $H E$ iv.11.3-10) appears to summarise the same document to which Theodoret has access: Athanasius and Constantius, 118 , 210. Barnes (p. 276 n. $5^{6}$ ) also says that Ursacius and Valens were present, according to Sozomen's account. However, Sozomen does not say that the two Illyrians were present, merely that Liberius presented Constantius with their letter to Julius.

${ }^{71}$ Athanasius, Epistula ad episcopos Aegypti et Libyae 7.3 (Metzler, 46). Also listed are Secundus of Pentapolis, George of Laodicea and Leontius and Stephanus of Antioch; cf. Gwynn, The Eusebians, 113. $7^{2}$ Barnes, Athanasius and Constantius, 123.

73 Historia acephala 4.7 (Martin and Albert, 158); cf. Barnes, Athanasius and Constantius, 160-1.

74 Philostorgius, HE ix.10, in Philostorgius Kirchengeschichte, ed. Joseph Bidez, GCS, Berlin 1981, 119-20. I follow the dating of Hanson, The search, 616. 
have confused Theodore with Dorotheus, a later bishop of Heraclea, so his report is of little use. 75

Moreover, in addition to Liberius' statement from 355, there is further evidence that Theodore had passed from the scene by at least 364 . Sozomen recorded that a group of bishops willing to accept the term homoousios selected Hypatian of Heraclea to approach the emperor Valentinian in the spring of 364 with the request to convene a new council, so it is clear that by this point Theodore had indeed died and did not live to the late 360 s to consecrate Demophilus as Philostorgius suggested. $7^{6}$ Furthermore, the fact that Socrates mentioned Hypatian in his muddled reference to Sirmium $35^{1 / 357}$ perhaps indicates that the new bishop of Heraclea was present at the Second Council of Sirmium in 357 , while Theodore, as we have seen, was present at the first. 77 The report in the Historia acephela is left as a possible witness to Theodore living beyond Liberius' interview in 355 , but in the face of these conflicting reports, greater credence should go to Liberius since his reference is explicitly to Theodore of Heraclea, and the Historia acephala is generally regarded as being condensed and at times confused.

Theodore's appearance at several critical junctures in the disputes of the $33^{\circ}-35^{\text {Os }}$ shows him to be a significant ecclesiastical politician who represented the interests of the Eusebian alliance during this period. $7^{8}$ In fact, for nearly every key event from 334 to 355 for which there is

75 Philostorgius, HE ix.14 (Bidez, 120); cf. Socrates, HE iv.35.4 (Hansen and Sirinjan, 27o); Sozomen, $H E$ vi.37.17 (Bidez and Hansen, 297). Sozomen also records (vii.14.4; Bidez and Hansen, 319) that this Dorotheus became bishop of Constantinople after the death of Demophilus, since he was regarded as better qualified than Marinus.

${ }^{7}$ Sozomen, $H E$ vi.7.1 (Bidez and Hansen, 245); cf. Hanson, The search, 763 n. 128 , who hesitates to give a firm date for the council, and Barnes, Athanasius and Constantius, 161, who argues for a date of 364 . See Barnes's argument that Sozomen's account of this event is to be trusted more than Socrates, HE iv.2: Athanasius and Constantius, 291 n. 63 .

77 Socrates, HE ii.29.2-3. So Martin and Albert, Histoire 'Acéphale', 198 n. 107. Hypatian was also possibly involved in the publication of the Homoian Creed in 359 (so Barnes, Athanasius and Constantius, 144, 284 n. 2). His name is listed in a letter of George of Laodicea that is preserved in Epiphanius, Panarion lxxiii.22.5-8, but is not included in the list contained in the letter of Germinius in Hilary, Fragmenta historica, ser. B vi.3 (Feder, 163 ).

$7^{8}$ Hanson, The search, 284; cf. Schäferdiek, 'Er gehört offenbar zu einem festen Kontinuitäts- und Führungskern, der sich innerhalb des Kreises der tonangebenden Bischöfe der östlichen Mehrheitspartei der dreißiger Jahre herausbildet': 'Theodor von Herakleia', 397; cf. Philostorgius, $H E$ viii.1 7 (Bidez, 115) who lists Theodore and George of Laodicea as the most celebrated of those who held to the ópooviotov. His mention of Theodore's adherence to ópoov́бıv seems unlikely, but his assertion of Theodore's recognised leadership role is plausible. Moraitis also stresses Theodore's significance as a leader of the Eusebian alliance during this period: 'Theodoros, Bischof von Herakleia', $1479-85$. 
evidence of attendees, Theodore is present, usually serving in a leading role. From what can be gleaned from the historical accounts it appears that, like others in the Eusebian alliance, he was resolutely opposed to Marcellus on theological grounds and to Athanasius on the basis of the charges brought against him at Tyre. Moreover, as bishop of a see near Constantinople, he was involved in several attempts to resist the efforts of Paul to take the bishop's seat in the capital. The documents from Serdica denounce Theodore and his associates as 'Arians' who were scattering abroad heretical teachings. However, unlike most of the others who were condemned during these years, Theodore left behind a literary corpus which survived into the fifth century, and, at least in part, to the present day. We shall now have to consider these literary remains and their reception to see how they compare with the impression gleaned from Theodore's career.

\section{The writings of Theodore of Heraclea}

In this section Theodore's extant writings will be briefly introduced, and it will be argued that they largely confirm the impression given by the account of his life. Moreover, it will be suggested that Theodore's concern to refute Montanism illustrates the theological diversity of the Eusebian alliance, since anti-Montanist polemic does not figure prominently in other Eusebian authors. Finally, it might be the case that Theodore implied a connection between Marcellus and Montanism, something which is also hinted at in a handful of other sources from the fourth and fifth centuries.

In 392 Jerome mentioned Theodore in his De viris illustribus, stating that 'during the reign of Emperor Constantius he published commentaries on Matthew and John and on the epistles and on the Psalms, marked by a critical and clear expression and a rather historical sense'.79 Later, writing during the mid-fifth century, Theodoret noted that he 'was especially learned, and had written an exposition of the holy gospels'. ${ }^{80}$ Only fragments survive from Theodore's writings, all coming from the catenae. Quite a few fragments attributed to him apparently come from a Commentary on Isaiah and are collected in $P G$ xviii.1307-78, though it is curious that Jerome made no mention of this work. These fragments have never been subjected to any scholarly scrutiny, so some study would be

79 Jerome, De viris 9o, PL xxvi.20. See also Jerome, Epistula cxii.20, in Isidorus Hilberg, Sancti Eusebii Hieronymi Opera: Epistulae LXXI-CXX, CSEL lv, Leipzig 191 2, 39o, where he mentioned that Theodore commented upon the Psalms; and Jerome, Commentarii in evangelium Matthaei, praef, in Saint Jérôme: Commentaire sur s. Matthieu, Tome I, ed. Émile Bonnard, SC ccxlii, Paris 1977, 68, where he said that he consulted Theodore's Commentary on the Gospel of Matthew.

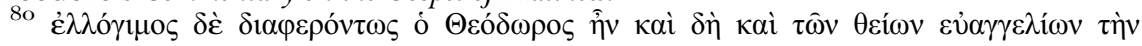

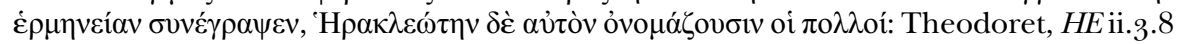
(Parmentier and Hansen, 97). 
needed to determine whether they are authentic. There are a few fragments on the Psalms attributed to him as well, fitting with Jerome's report, but the authenticity of these has been called into question. ${ }^{81}$ In his letters Jerome also made reference to brief commentaries on Acts by Theodore, of which three fragments are extant, as well as a commentary on the Pauline Epistles which appears to have been entirely lost. ${ }^{82}$

Theodore's commentaries on the Gospels, mentioned by both Jerome and Theodoret, have left the largest amount of surviving material. In his study of the Gospel catenae traditions, Reuss carefully sifted the manuscript evidence and edited 134 fragments from his Commentary on the Gospel of Matthew and 430 fragments from his Commentary on the Gospel of John. ${ }^{83}$ There are few fragments extant on the first eight chapters of the Gospel of John, but from chapter ix on the catenae preserve a fragment from Theodore for nearly every passage. Reuss also published one fragment that purports to be from Theodore's Commentary on the Gospel of Luke, but this attribution is questionable, for half of the fragment is identical to a fragment from the Commentary on the Gospel of Matthew. ${ }^{84}$ Little study of Theodore's exegesis exists. Reuss situates him in the Antiochene tradition,

81 Devreesse doubts the authenticity of these fragments: Les Anciens Commentateurs, 328. Rondeau considers the commentary to be completely lost and wonders if Jerome might have confused Theodore of Heraclea with Theodore of Mopsuestia who left behind a Commentary on the Psalms that is well attested: Les Commentaires patristiques, i. $75^{-6 .}$.

${ }^{82}$ For the fragments on Acts see J.A. Cramer, Catence grecorum patrum in Novum Testamentum, iii, Hildesheim 1967, 145; cf. Jerome, Epistula cxix.2 (Hilberg, 447): 'theodorus heracleotes, quae urbs olim perinthus uocabatur, in commentariolis apostoli sic locutus est'. Mention of the commentary on the Pauline literature is to be found in Jerome, Epistula cxii.4.(Hilberg, 371), which is but a quotation from the preface to his Commentary on Galatians: Commentarii in epistulam Pauli apostoli ad galatas, ed. Giacomo Raspanti, CCSL lxxviiA, Turnhout 2006, 6.

Parvis, Marcellus of Ancyra, 186 n. 56, raises the intriguing possibility that the anonymous work On the Holy Church, composed around 340 and now regarded by many as coming from the pen of Marcellus, was written as a response to Theodore's exegesis of Ephesians iv.5 (now apparently lost). The work is addressed either 'to' or 'against' an otherwise unidentified 'Theodore'. For the text see A.H. B. Logan, 'Marcellus of Ancyra (Pseudo-Anthimus), "On the Holy Church": text, translation and commentary', JTS li (2000), 81-1 12. Perhaps further comparison of this text with the literary remains of Theodore could shed light on this question.

${ }^{83}$ Reuss, Matthäus-Kommentare, 55-95, and Johannes-Kommentare, $65^{-176}$. Note, however, that some of the fragments that Reuss included from the catena on Matthew are actually attributed to a Thaddaeus of Heraclea, but he considered the appellation to be a textual corruption, and so attributes the fragments to Theodore of Heraclea. He also published a number of fragments attributed in the manuscripts simply to 'Theodore', which could refer either to the bishop of Heraclea or to that of Mopsuestia, but he distinguished these passages from those that were unambiguously attributed to one or the other.

${ }^{8}$ Reuss, Lukas-Kommentare, p. xxii; cf. Theodore of Heraclea, Fragmenta in Lucam, no. 1 (Reuss, 65), and Fragmenta in Matthaeum, no. 78 (Reuss, 78). 
describing him as 'einen gewandten, nüchternen Exegeten, der den Grundsätzen der antiochenischen Schule huldigt, der in allem den wirklichen Sinn des Schriftwortes in möglichst klarer Weise vorlegen will', an opinion with which Schäferdiek concurs. ${ }^{85}$ A more extensive treatment of his exegetical method is not possible in this context, but further study is needed to clarify where his exegetical corpus fits into the larger picture of patristic exegesis, especially since the traditional notion of two competing exegetical schools in Antioch and Alexandria has been recently challenged. Schäferdiek himself admits that Theodore offers a less than literal interpretation of the gospel parables, which might imply that the label 'Antiochene' fails to do justice to his exegetical approach. ${ }^{86}$

Reuss pointed to approximately seventeen instances in which there exists a dual recension of the fragments from Theodore, and noted some differences between them, which are attributable to the different ways in which the catenists extracted from their sources. ${ }^{87}$ In these instances, although there is not an exact correspondence of wording, we can assume that we are still working with material that is largely from Theodore which might simply have been paraphrased. However, as Schäferdiek has pointed out, there is some language in the fragments attributed to him that

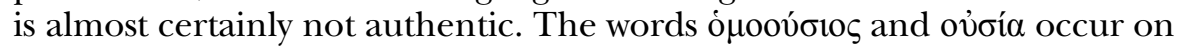
several occasions, terms unlikely to come from the pen of a leader of the Eusebian alliance. ${ }^{88}$ Their occurrence is either due to some confusion of authorship in the catena tradition, or to the catenists' updating Theodore's extracts to bring them into line with the language of later orthodoxy. The number of passages containing such language is relatively small compared with the total amount of surviving material, so it should not be assumed that Theodore's literary remains have been so tampered with that they are of little use for understanding the fourth century.

In fact, several features of the fragments confirm what we would expect from this period. To take one example, the repeated use of $\pi \rho$ ó $\sigma \omega \pi$ ov and i $\pi_{0} \sigma \tau \alpha \sigma ı \varsigma$ to refer to the individual existence of Father, Son, and Spirit is in keeping with what we know of the Eusebian alliance. The second

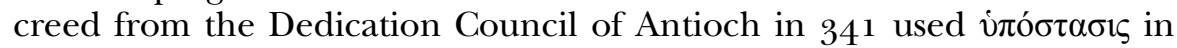

85 Reuss, Matthäus-Kommentare, p. xxviii; cf. Schäferdiek, 'Theodor von Herakleia', 404-6. The only studies of Theodore's exegesis are in Reuss, Matthäus-Kommentare, pp. xxvi-xxix, and Johannes-Kommentare, pp. xxii-xxiii; Schäferdiek, 'Die Fragmente', 185-7; and Schäferdiek, 'Theodor von Herakleia', 404-10. His treatment of the parable of the workers in the vineyard is briefly noted in J. M. Tevel, 'The labourers in the vineyard: the exegesis of Matthew 20, 1-7 in the early Church', Vigiliae Christianae xlvi (1992), 356-80.

87 Reuss, Johannes-Kommentare, p. xxi.

88 ómoov́бıs, in Fragmenta in Matthaeum, nos 133, 134 (Reuss, 94, 95); Fragmenta in Joannem, nos 257, 334 (Reuss, 132, 153). ov̉oía in Fragmenta in Matthaeum, nos 133, 134 (Reuss, 94, 95); Fragmenta in Joannem, nos 66, 126, 254, 257, 302, 310, 315, 334, 336, 343 (Reuss, 82-3, 99, 131, 132, 144, 146, 148, 153, 155). 
this sense, and the nineteenth anathema from the Council of Sirmium $35^{1}$ used $\pi \rho \sigma^{\sigma} \sigma \omega \pi \mathrm{v}^{8}{ }^{89}$ Theodore seems to have used i $\pi$ ó $\tau \alpha \sigma 1 \zeta$ to mean 'individual, circumscribed existence', a definition that he could have picked up from Origen. $9^{\circ}$ The usage of these terms is linked in Theodore's fragments with a concern to oppose Monarchianism. There are four extracts in which Sabellius or his followers are named, and, in these instances Theodore used several of the Father-Son passages in the Gospel of John (John viii.17-18; xii.49-50; xiv.10, 23) to argue that the Father

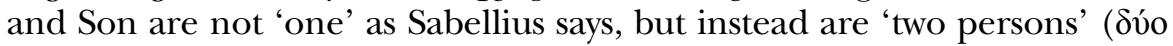
$\pi \rho o ́ \sigma \omega \pi \alpha) .9^{1}$ Schäferdiek suggests that it is all but certain that these fragments are directed against Marcellus, the most prominent proponent of a Monarchian theology in Theodore's own day. Parvis and Lienhard have both noted the tendency among some fourth-century authors to oppose Marcellus through the proxy of Sabellius, and Theodore appears to be further evidence of this trend. $9^{2}$

This supposition finds confirmation in the fact that on two occasions in the surviving fragments Theodore explicitly named and opposed Marcellus.93 In John xvii.4-5 Jesus prayed that the Father would give him the glory that he had before the world existed. In fragment 333, which comments on this passage, Theodore charged Marcellus with denying that the Son received glory from the Father, and saying instead that he

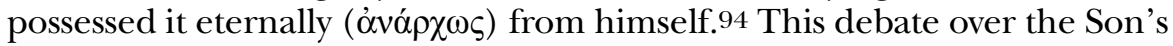
eternal glory probably goes back at least to Asterius, since, in a surviving Marcellan fragment, Marcellus denies Asterius' claim that the 'authority given to the Son' was his 'glory before the world existed', and he says instead that before the world existed 'there was nothing except God alone'. 95 Theodore, then, might be continuing this debate by responding to Marcellus' anti-Asterian polemic regarding the 'glory' of the Son.

${ }^{89}$ For the use of $\pi \rho{ }^{\circ} \sigma \omega \pi$ ov see Fragmenta in Joannem, nos $56,111,215,261,268,312$

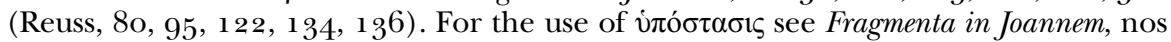
$261,265,270,344$ (Reuss, 134, 135, 136, 156). I have left out those passages that

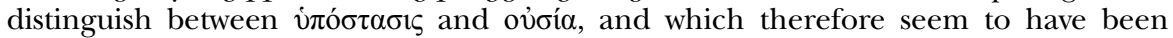
interpolated.

90 See Fragmenta in Joannem, nos 255, 265 (Reuss, 131, 135). The phrase comes from Ayres, Nicaea and its legacy, 25, who is describing Origen's usage of the word. On Theodore's possible indebtedness to Origen see Matthew R. Crawford, 'The triumph of pro-Nicene theology over anti-monarchian exegesis: Cyril of Alexandria's critique of Theodore of Heraclea', Journal of Early Christian Studies (forthcoming).

${ }^{1}$ Fragmenta in Joannem, nos 56, 215, 255, 269 (Reuss, 80, 122, 131, 136); cf. Schäferdiek, 'Theodor von Herakleia', 408.

$9^{2}$ Schäferdiek, 'Die Fragmente', 1 86, 190; Parvis, Marcellus of Ancyra, 251; Lienhard, Contra Marcellum, 21 off. ${ }_{93}$ Fragmenta in Joannem, nos 40, 333 (Reuss, 76, 152).

94 Ibid. 333 (Reuss, 152 ).

95 Marcellus, Fragmenta, no. 77, in Markus Vinzent, Markell von Ankyra: die Fragmente: der Brief an Julius von Rom, Leiden 1997, 68; cf. Marcellus, Fragmenta, no. 114; and 
Moreover, Theodore's description of Marcellus' teaching in fragment 333 also has resonances with the profession of faith put forward by the westerners at Serdica, which asserted that the Word existed 'eternally and has no beginning ( $\left.\dot{\alpha} \rho \chi \eta^{\prime} v\right)^{\prime} .9^{6}$ Although it is unclear how much Marcellus directly or indirectly influenced the Serdican profession, it certainly emanated from a milieu in which he was favoured, and one in which Theodore was perceived to be an enemy. 97 The same idea also arose as a point of contention at the Council of Sirmium (351), where Theodore was likely in attendance. There the bishops anathematised those who say

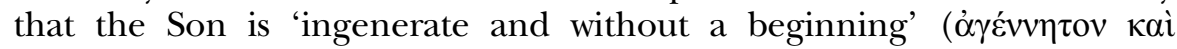

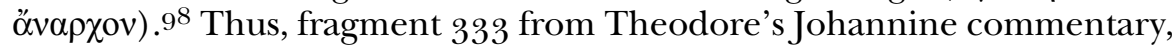
which attacks the notion that the Son has eternal glory, resonates with the Eusebian perception of Marcellus at Serdica and Sirmium 351, as well as with the surviving Marcellan fragments.

Two further themes in Theodore's fragments suggest links with Marcellus - the concern to uphold the preexistence of the Son prior to the incarnation and the attempt to refute psilanthropism. Although Theodore denied Marcellus' claim that the Son had glory from himself 'eternally' he nevertheless wanted to maintain that the Son existed

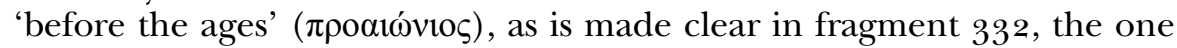
immediately preceding the passage just considered.99 The same issue is at stake in Theodore's fragment 344 on John xvii.24. Here Theodore speaks of 'those who say [the Son] received his beginning from the virgin Mary'. Against such persons, the words of Jesus in the Gospel manifest the hypostases of the Father and Son and teach that he existed before the world. ${ }^{100}$ Marcellus had emphasised the Saviour's birth from the virgin as the beginning of the 'second economy', which was apparently taken by some Eusebians to imply that the Son's existence does not begin until the incarnation. ${ }^{101}$ As Lienhard points out, the westerners at Serdica had to defend Marcellus against the accusation that he taught that the Word had 'a beginning from the holy virgin Mary'. ${ }^{102}$ The same issue surfaces in the anti-Marcellan statements from Sirmium $35^{1}$. Immediately after condemning those who say that the Son is 'without a beginning', the bishops went on to

Parvis, Marcellus of Ancyra, 168. I am using Vinzent's numbering of the Marcellan fragments here and in what follows.

$9^{6}$ Theodoret, HE ii.8.42 (Parmentier and Hansen, 115 ).

97 Lienhard says that Marcellus 'probably influenced its composition': Contra Marcellum, 6.

$9^{8}$ Athanasius, De synodis 27.3.26. Lienhard identifies the notion of the Son not possessing 'eternity' as a hallmark of Eusebian theology: Contra Marcellum, 39.

99 Fragmenta in Joannem, no. $33^{2}$ (Reuss, 152). ${ }_{100}$ Ibid. no. 344 (Reuss, 156 ).

${ }_{101}$ Marcellus, Fragmenta, nos 9, 74; cf. Lienhard, Contra Marcellum, 58-6o.

${ }_{102}$ Lienhard, Contra Marcellum, 148, who calls the accusation 'absurd'. For the accusation see Hilary, Fragmenta historica, ser. B ii.1.6 (Feder, 11 7-18). 
anathematise those who deny that the Son is 'before the ages' ( $\pi \rho 0 \alpha i \omega$ vios), the same pattern that we see in Theodore's fragments. ${ }^{103}$

This concern to demonstrate the preexistence of the Son is connected in Theodore's fragments with an attempt to refute the notion that the

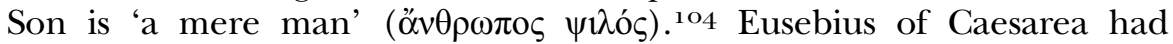
previously charged Marcellus with psilanthropism, and Theodore's fragment suggests that he perpetuated this accusation in his own antiMarcellan work. ${ }^{105}$ These anti-Monarchian passages emphasising the Son's distinction from the Father, the Son's reception of glory from the Father, and the Son's preexistence are exactly what we would expect from a member of the Eusebian alliance who played a leading role at Serdica and Sirmium 351, and who likely would have been familiar with Eusebius' earlier anti-Marcellan writings.

There is at least one other feature of these fragments that also ties in with Theodore's ecclesiastical career. On four occasions the Montanists are mentioned and their theology opposed. ${ }^{106}$ Other fourth-century authors oppose Montanism, so Theodore's mention of the movement is not that unusual in the broader context of the fourth century. ${ }^{107}$ However, aside from Eusebius of Caesarea who wrote about the Montanists in his Ecclesiastical history, Theodore appears to be the only Eusebian theologian in our extant sources who presents a concern with the 'Phrygian heresy'. Nevertheless, there is some evidence to suggest that one strategy employed by the Eusebians in the anti-Marcellan campaign was to smear their opponent with the Montanist label. In his account of the dispute over the term homoousios that followed shortly after Nicaea, Socrates notes that those who opposed the term accused its supporters of holding the opinion of Sabellius and Montanus, a report confirmed by Sozomen. ${ }^{108}$ Later, in his discussion of the Nestorian controversy, Socrates lumps together the errors of Photinus, an associate of Marcellus, and Montanus as both denying the subsistence of the Son. ${ }^{109}$ Moreover, at the Council of Serdica where Theodore likely took a leading role, the easterners sought to discredit Marcellus by connecting him to Paul of Samosata, Sabellius and Montanus, the latter being 'the leader of all the heretics'. ${ }^{10}$ It has long been recognised that those in the Eusebian alliance often linked Marcellus with Sabellius, but in contrast it was relatively rare for these authors to connect

103 Athanasius, De synodis 27.3.27. ${ }^{104}$ Fragmenta in Joannem, no. 332 (Reuss, 152). 105 Eusebius, De ecclesiastica theologia i.20.45; cf. Lienhard, Contra Marcellum, 1 24-5.

106 Theodore of Heraclea, Fragmenta in Joannem, nos 6o, 261, 271, 272. Part of Fragmenta in Joannem, no. 26o is also preserved in a Latin translation: testimony 85 in Ronald E. Heine, The Montanist oracles and testimonia, Macon, GA 1989, 110.

${ }_{107}$ See William Tabbernee, Fake prophecy and polluted sacraments: ecclesiastical and imperial reactions to Montanism, Leiden 2007, $263 \mathrm{ff}$.

${ }_{108}$ Socrates, HE i.23.7 (Hansen and Sirinjan, 7o); Sozomen, HE ii.18.3 (Bidez and Hansen, 74). On the latter passage in Sozomen see Ayres, Nicaea and its legacy, 101.

${ }^{109}$ Socrates, HE vii.32.20. ${ }^{110}$ Hilary, Fragmenta historica, ser. A iv.1.2 (Feder, 50). 
him also with Montanus, leading Lienhard to note the oddity of the mention of Montanus in the letter from the Eusebians at Serdica. ${ }^{11}$ I suggest that Theodore's apparent concern over Montanism provides some context that helps to make sense of this otherwise obscure reference.

Although Theodore does not explicitly connect Marcellus to Montanus in the extant fragments of his commentaries, such a linkage is implied in fragment 261 , in which he comments upon John xiv.15-16 ('If you love me, you will keep my commandments. And I will ask the Father, and he will give you another Paraclete.'). Here, initially, Montanus is named and his heresy is opposed, but by the end of the fragment Theodore is condemning Monarchian theology:

Because the apostles did the will of God in every way and died for him, it is clear that they kept his commandments. Therefore, they were at once deemed worthy also of the indwelling of the Holy Spirit. And those who say that the Paraclete was sent after 230 years through Montanus, Priscilla, and Maximilla (that is, the heresy of the Phrygians) are deceived. Insofar as he says he will ask the Father to send another Paraclete, he clearly demonstrates the three persons of the one Trinity ( $\tau \dot{\alpha}$ $\left.\tau \rho i ́ \alpha \pi \rho \sigma^{\prime} \sigma \omega \pi \alpha \tau \eta \hat{\varsigma} \varsigma \mu \hat{\alpha} \varsigma \tau \rho \imath \alpha \dot{\delta} \delta \varsigma\right)$. For no one says that so-and-so asks himself and sends himself - which is precisely what those who confuse the hypostases claim. ${ }^{112}$

In this short fragment it is clear that Theodore wishes to make two points. First, because the Apostles kept the Lord's commandments, they immediately received the Spirit, rather than 230 years later. Second, because the passage speaks of the Father, of Jesus and of the Paraclete, it is nonsensical to claim that there is no irreducible distinction between the three. The Montanists are explicitly named as being the object of the first criticism. Theodore does not name an opponent with respect to his second point, so it is not clear if the Montanists are still in view. Nevertheless, the juxtaposition of these two concerns in such close proximity might imply some connection in Theodore's mind between the Montanist and Monarchian heresies.

D. H. Williams has postulated 'an indirect theological similarity' between Monarchianism and Montanism in the fourth century, and Theodore's fragments seem to support his hypothesis, though we should note that this similarity might have more to do with the perception of Montanism in the fourth century, rather than with what Montanists might actually have

\footnotetext{
111 Lienhard, Contra Marcellum, 173 n. 22.
}

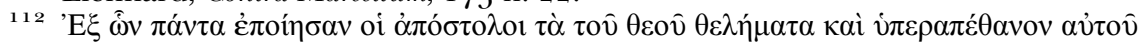

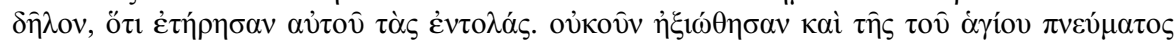

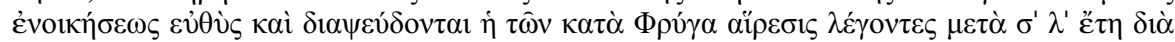

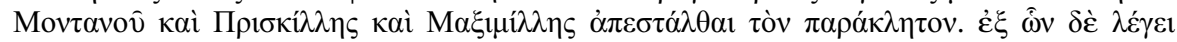

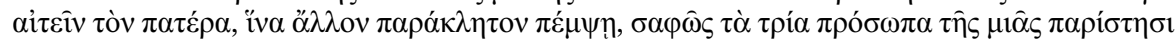

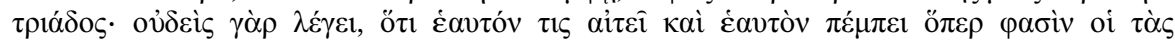

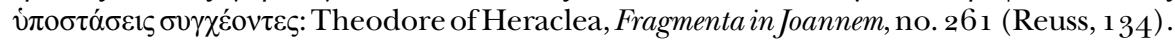


been teaching at this point. ${ }^{13}$ In addition to fragment 261 , another of Theodore's surviving extracts preserves a Montanist logion that implies the sort of 'theological similarity' perceived by Williams. Here Montanus is reported as saying, ' $\mathrm{I}$ am the Logos, the Bridegroom, the Paraclete, the Almighty, I am everything.' ${ }^{114}$ In light of such a Montanist oracle that appears to conflate the divine three, it is not surprising that the Eusebians would exploit this similarity in their campaign against Marcellus' Monarchianism at Serdica. Though it is impossible to prove conclusively, it is plausible that Theodore's influence lies behind the attempt to condemn Marcellus as a Montanist in the eastern encyclical from Serdica.

The picture that emerges from this brief survey demonstrates theological concerns that fit within what we know of the Eusebian alliance during the years of Theodore's activity. The most obvious feature that marks Theodore's writings is his concern to oppose Marcellus, which is not surprising since the deposed bishop of Ancyra was the foremost theological opponent of the Eusebians during these years. Moreover, Theodore's fragments add credence to the hypothesis that fourth-century authors viewed Montanism as a sort of Monarchian error, and that they used this perception in their campaign against Marcellus. Even if a handful of his fragments have been interpolated, as seems likely, further study of this sizeable body of literature would undoubtedly give a fuller account of the theology and exegesis of those in the Eusebian alliance.

\section{The reception of Theodore in the later patristic tradition}

Theodore's literary activity influenced his contemporaries and successors, and his reception among both non-Nicenes and pro-Nicenes indicates the insufficiency of the unnuanced 'Arian' label used to describe him in the western documents from Serdica. Most notably, one fragment from Theodore's Commentary on the Gospel of John, an explanation of John vi.9 is identical to a surviving fragment from the Gothic Commentary on the Gospel of John, also known as the Skeireins. ${ }^{115}$ Furthermore, like Theodore's surviving Greek fragments, the Skeireins also polemicises against Sabellius

113 D. H. Williams, 'Monarchianism and Photinus of Sirmium as the persistent heretical face of the fourth century', Harvard Theological Review xcix (2006), 190. See also the Montanist logion, noted by Williams, that sounds similar to the Theodorean fragment above: Ps-Didymus, De trinitate iii.41.1, $P G$ xxxix.98 8 B.

${ }^{114}$ Fragmenta in Matthaeum, no. 44 (Reuss, 148). Reuss included this fragment in his section of fragments simply attributed to Theodore, indicating that it could be the bishop of Heraclea or his namesake the later bishop of Mopsuestia. Since our Theodore elsewhere attacks Montanism, it seems most likely that this extract belongs to him.

${ }^{115}$ Schäferdiek provides the Gothic text alongside the Greek text: 'Die Fragmente', ${ }_{176-7}$. For the Gothic text and an English translation see The Gothic commentary on the 
and Marcellus for holding to a Monarchian heresy. ${ }^{116}$ Based on this identification, and on the general theological and exegetical tenor of the two works, Schäferdiek proposes that the Skeireins is actually a Gothic translation of Theodore's commentary. ${ }^{117} \mathrm{He}$ tentatively raises the possibility that Theodore might have met Ulfilla, bishop of the Goths, who could have served as the medium for conveying Theodore's works to the Goths. ${ }^{118}$ Philostorgius mentions anonymous 'others' with Eusebius who were present at Ulfilla's ordination, and given Theodore's close proximity to the capital and his frequent association with Eusebius, it is reasonable to suspect that he would have had a hand in ordaining the bishop to the Goths. ${ }^{119}$ If the identification of the Skeireins with Theodore's Johannine commentary is correct, as seems likely, then Theodore served as a key conduit conveying anti-Marcellan, Eusebian theology to the Goths.

In addition to this striking similarity between Theodore's fragments and the Skeireins, there is also evidence of Theodore's influence among proNicenes. Reuss pointed out significant similarities between his explanation of John xii. 6 and that by Chrysostom on the same text, similarities striking enough to conclude that some sort of textual relationship must exist between the two sources. ${ }^{120}$ However, the two texts are so similar that we might be justified in wondering whether the catena fragment is wrongly attributed to Theodore and should instead be regarded as Chrysostom's. Nevertheless, Reuss said that a comparison between Chrysostom's Johannine homilies and Theodore's extant fragments shows that Chrysostom must have 'repeatedly' ('immer wieder') used Theodore's commentary, although he gave no other specific instances of dependency. ${ }^{121}$ Further study is needed to substantiate this claim. Also relevant is the Johannine commentary by Ammonius of Alexandria, which was likely written during the second half of the fifth century or early sixth century. According to Reuss, Ammonius used Theodore's work when commenting on John viii.17-18, 47; xi.34-5. ${ }^{122}$ Finally, we should add to this list the

Gospel of John, ed. W. H. Bennett, New York 1960, 75. The fragment in question is Skeireins VIIa. ${ }_{116}$ Skeireins IVd (Bennett, 66).

${ }_{117}$ Schäferdiek provides a detailed examination of the relationship of the Skeireins to Theodore's extant literary fragments and demonstrates many similarities in the two sources: 'Die Fragmente', 185-93. As he notes, the suggestion that the Skeireins might be a Gothic translation of Theodore's work was made by the editor of the first edition of the Gothic fragments: H.F. Massmann, Auslegung des Evangelii Johannis in gothischer Sprache, Munich 1834 .

119 Philostorgius, HE ii.5 (Bidez, 18 ).

120 See Theodore of Heraclea, Fragmenta in Joannem, no. 177 (Reuss, 111 ) and John Chrysostom, Homiliae in Joannem lxv, PG lix.363.

${ }_{121}$ Reuss, Johannes-Kommentare, p. xxi.

${ }^{122}$ Idem, 'Der Presbyter Ammonios von Alexandrien und sein Kommentar zum Johannesevangelium', Biblica xliv (1963), 159-70. 
catenists themselves who made excerpts from the works of the bishop of Heraclea. If it had not been for their efforts we would have nothing left of his literary corpus.

In addition to Chrysostom, Ammonius and the later catenists, Jerome's praise of Theodore in his work should be recalled. He claimed to have had access to Theodore's works, and it is reasonable to suppose that he had also read Athanasius' historical works, yet the only hint of historical context that he offered for Theodore's life was that he wrote during the reign of Constantius, which does not even specify on which side of the political dispute he stood. ${ }^{123}$ Theodoret was also clearly informed about Theodore's political associations, since he wrote about his role in the Ecclesiastical history and also had access to the documents from Serdica, but he too mentioned nothing objectionable about Theodore's works, and even offers a hint of praise. The silence of Jerome and Theodoret regarding any error contained in Theodore's works is telling. This generally positive reception among later pro-Nicenes suggests that his commentaries were hardly the overtly 'Arian' works that one would expect to find based on the statements from the Council of Serdica and Athanasius.

In fact, aside from the Athanasian historical literature, there is only one negative remark made about Theodore's works in the centuries following his death, and it emanates from a resoundingly pro-Athanasian context. Cyril of Alexandria, writing during the 420 , took an extended excursus in his Commentary on the Gospel of John to cite and then refute two passages from an unnamed 'Arian' heretic. One of these citations is an identical match for an extract of Theodore's from the catena tradition, and although the second citation does not survive elsewhere, it too is representative of this stage of the 'Arian' conflict in that it uses hypostasis and ousia synonymously. ${ }^{124}$ What is particularly notable is the way in which Cyril approached Theodore's work. Before offering any quotation from the exegetical writing of the bishop of Heraclea, he introduced the following discussion as a refutation of the 'heretical fighters against God' ( $\tau$ ois

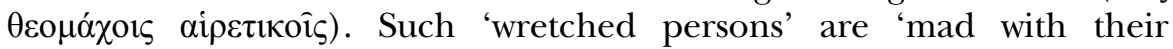
reproaches against Christ', and the source of their knowledge about Christ is not the Spirit or the revelation from the Father, but rather 'the

123 On Jerome's knowledge of Athanasius see J. N. D. Kelly, Jerome: his life, writings, and controversies, London 1975, 64. Kelly follows earlier studies by P. Batiffol, 'Les Sources de l'Altercatio Luciferiani et Orthodoxi de saint Jérôme', Miscellanea Geronimiana, Rome 1920, 97-113, and Y. Duval, 'Saint Jérôme devant le baptême des hérétiques', Revue des études augustiniennes xiv (1968), 145-81.

${ }_{124}$ The first fragment is found at Cyril, Commentarius in Joannem ix.1, in Sancti patris nostri Cyrilli archiepiscopi Alexandrini in D. Joannis evangelium, ed. P. E. Pusey, Oxford 1872 , ii. 434). It is identical to Theodore of Heraclea, Fragmenta in Joannem, no. 255 (Reuss, 1 $3^{1}$ ). The second fragment is quoted twice at Cyril, Commentarius in Joannem ix.1 (Pusey, ii. 443, 449-5 ); cf. Crawford, 'The triumph of pro-Nicene theology'. 
head of the dragon'. ${ }^{125}$ They have drunk the 'wine of Sodom' and the 'bitter grapes of Gomorrah', and thus 'do not think soundly, but speak those things that make the souls of their hearers wretched, bringing them down to Hades and into the abyss below'. By publishing these ideas in books, they 'set up an immortal monument of the wickedness that is in them'. ${ }^{126}$

Such a description of Theodore is a far cry from the praise that he received from Jerome and Theodoret. It is important to note what these two fragments are not. Neither of them represents the sort of radically 'Arian' subordinationist theology that one would expect to find based on the documents from Serdica and from the Athanasian historical writings. Rather, the fragments are best read as a criticism of the Monarchianism of Marcellus, since they both attempt to distinguish between the Father and the Son so as to avoid conflating the two divine persons. It is true that the latter fragment does so by distinguishing between the ousia of the Father and the Son, but Theodore was writing at a stage of the controversy when ousia language was not clearly distinguished from hypostasis, and was still regarded by many as bearing troubling material connotations. ${ }^{127}$ Moreover, Cyril himself admits twice that his unnamed author says that Christ is God, which indicates that the debate of the fourth century was not simply whether or not Jesus was divine, but more precisely the very definition of deity itself. ${ }^{128}$ Cyril's apparent desire is to portray Theodore as an 'Arian' heretic, and yet the only evidence that he can produce from his writing are these two fragments, neither of which accomplishes this purpose for him.

When Cyril speaks against Theodore, he does so as the bishop of Alexandria, heir of Athanasius' see and defender of his theology. Furthermore, he was certainly aware of the Athanasian historical writings, as well as the texts from Serdica. In fact, there are intriguing parallels with the Serdican Synodical letter to all churches that suggest it has probably inspired Cyril's criticism of Theodore. One of the biblical passages cited in the letter is John xiv.10, 'I am in the Father, and the Father is in me', which is presented as proof that the Father, Son and Holy Spirit share one hypostasis, which 'the heretics' call an ousia. ${ }^{129}$ Moreover, the letter asserts that Theodore and the other excommunicated bishops 'separate the Son

\footnotetext{
125 Asserting the diabolical origin of heresy is a classic topos of early Christian literature, and one that Athanasius himself used against the 'Arians': Athanasius, De sententia Dionysii 3; De decretis 2; Gwynn, The Eusebians, 173.

${ }_{126}$ Cyril, Commentarius in Joannem ix. 1 (Pusey, ii. 433).

127 See Ayres, Nicaea and its legacy, 92-8.

128 Cyril, Commentarius in Joannem ix. 1 (Pusey, ii. 435, 443). So also Ayres, 'At issue until the last decades of the controversy was the very flexibility with which the term "God" could be deployed': Nicaea and its legacy, 14.

129 Theodoret, HE ii.8.39-41 (Parmentier and Hansen, $113-14$ ).
} 
from the ousia and divinity of the Father'. ${ }^{130}$ The passage upon which Cyril chose to quote and refute Theodore is precisely John xiv.10-1 1, and the most damning charge that he brought against him is that Theodore's 'one purpose' (бколо́ $\varsigma$ ) is to show that the Son is 'entirely alien and foreign to the ousia of the Father'. ${ }^{13}$ Both Serdica and Cyril set themselves against Theodore, and they both do so by bringing the same charge against him and by producing the same biblical passage as evidence of their own position. In other words, in his Commentary on the Gospel of John, Cyril is perpetuating the condemnation of Theodore pronounced at the Council of Serdica some eighty years prior.

Further evidence for Cyril's familiarity with these writings comes from an unlikely source. The 'affair of Apiarius' at the Council of Carthage in 419 prompted the North African bishops to send envoys to the East to obtain authentic copies of the Nicene canons. Cyril's reply to their request is his ep. lxxxv, and in it he referred to an 'ecclesiastical history' that he sent along with the authentic copies of Nicaea. ${ }^{1{ }^{2}}$ C. H. Turner long ago argued that the Codex Verona LX $\left(5^{8}\right)$ contains portions of the dossier that Cyril sent to the council, and from what can be gleaned about the Alexandrian ecclesiastical history based on this codex, it is clear that it presented Theodore as an associate of Eusebius and an enemy of Nicene orthodoxy, who conspired with his fellow Eusebians to set a trap for Paul of Constantinople. ${ }^{133}$ In other words, Cyril not only inherited the Athanasian narrative of the fourth century, but also played a role in perpetuating and disseminating that narrative in the fifth century, as seen by his response to the North African bishops. I suggest that his attack on Theodore in his Commentary on the Gospel of John represents another example of this same impulse.

Thus, what we have in Theodore is a figure who was a significant leader in the pro-Eusebian alliance, whose works were profitably used by

$13^{\circ}$ Ibid. ii.8.34 (Parmentier and Hansen, 112 ); cf. Hanson, The search, 300-2.

131 Cyril, Commentarius in Joannem ix. 1 (Pusey, ii.449).

${ }^{132}$ The critical text of this letter is in P.-P. Ioannou, Fonti: Fascicolo IX: Discipline générale antique (IVe-IXe s), i/2: Les Canons des synodes particuliers, Rome 1962, 422-4.

133 See the tenth item in the codex, printed in PL lvi.146, as well as the twentysecond item in the codex, the so-called Historia acephala (1.2-6), which both name Theodore as a Eusebian. So also Martin and Albert, Histoire 'Acéphale', 40-1, 175 n. 12. It was thought by Turner and Schwartz that the Serdican material in the codex also came from Alexandria, but it is now generally regarded as coming from the Church of Thessalonica instead: Martin and Albert, Histoire 'Acéphale', 28-9. On the history of the codex see the introduction to Martin and Albert, Histoire 'Acéphale', as well as W. Telfer's important study, 'The Codex Verona LX(58)', Harvard Theological Review xxxvi (1943), 169-246. Telfer followed earlier work by C. H. Turner, 'The Verona Mss of canons: the Theodosian Ms and its connexion with St. Cyril', Guardian xi (Dec. 1895), 1921-2. He provides an index to the items in the codex at p. 185 , and discusses Cyril's connection to the manuscript at pp. $186-7$. 
Eusebians such as Ulfilla, and who also found acceptance and praise among some pro-Nicenes, but censure among others. This varied reception reflects an uncertainty about Theodore's status, an ambiguity that likely resulted from the gap that existed between the Athanasian narrative of the fourth century and the actual historical persons and events of the conflict. Moreover, it suggests that modern scholars were not the first to sense the inadequacy of an overly polarised account of these troubled years.

Theodore of Heraclea was a leading figure of the Eusebian alliance during the period 334-55. In fact, it seems likely that after the death of the first generation of Eusebians, including most significantly the two Eusebii themselves, Theodore rose in prominence. His association with Eusebius of Nicomedia and the proximity of his see to the imperial capital positioned him well to serve as a link between these earlier figures and those who perpetuated the movement after their passing.

The surviving fragments attributed to him both confirm what is known about his career and also add to our knowledge of the period. In his study of opposition to Marcellus, Joseph Lienhard stated that besides Eusebius of Caesarea, 'four other significant Christian writers of the fourth century attack Marcellus by name: Acacius of Caesarea, Eusebius of Emesa, Cyril of Jerusalem, and Basil of Caesarea'. ${ }^{134}$ On the basis of the preceding study, I suggest that Theodore of Heraclea should be added to this list. As one of the foremost figures in the Eusebian alliance during this period, he named and opposed Marcellus or Sabellius a half dozen times in the extant fragments, and undoubtedly has Marcellus in view in other fragments that do not explicitly name him. In addition, if Theodore is indeed the author of the Skeireins, then two more explicitly anti-Marcellan passages can be added to this list. ${ }^{135}$ Theodore's surviving writings, numbering into the hundreds of fragments, surpass the sparse literary remains of some other figures such as Acacius, and he therefore should be given more attention than he has received thus far. Moreover, Theodore is unique in that he chose to oppose Marcellus through the genre of commentary, rather than polemical tracts or homilies as had others. He also stands out for his concern with Montanism, which was likely connected to his opposition to Marcellus.

Finally, the varied reception of Theodore in the decades after his death reveals the insufficiency of viewing the conflict during the 330 - $35^{\text {os }}$ as one that was sharply divided along the lines of the more

134 Lienhard, Contra Marcellum, 208.

135 Skeireins IVd; Va-Vd (Bennett, 66-70). The first passage mentions 'Sabellius and Marcellus'. The second, lengthier than the first, only names Sabellius, but undoubtedly has Marcellus primarily in view. 
clearly anti- and pro-Nicene positions that crystallised after his death. The fact that later authors on both sides of the pro- and anti-Nicene divide availed themselves of Theodore's exegetical erudition demonstrates that his condemnation at Serdica in 343 did not hinder his having a broader influence, and suggests that his overriding theological concern was to oppose Marcellan Monarchianism rather than merely to subordinate the Son to the Father. In other words, Theodore is best understood when viewed in terms of the theological concerns of the Eusebian alliance during the $33^{\circ}-35^{\circ}$ os, rather than merely through the lens of the tendentious 'Arian' category constructed by Athanasius.

Jnl of Ecclesiastical History, Vol. 64, No. 2, April 2013. (C) Cambridge University Press 2013 doi:10.1017/Soo2204691300002X

\section{The Eusebius Essay Prize}

The Eusebius Essay Prize, of $£ 55$ oo, is offered annually for the best essay submitted on a subject connected with any aspect of early Christian history, broadly understood as including the first seven centuries AD/ CE. Scholars in any relevant discipline (theology, classics, late antique studies, Middle Eastern Studies etc.), whether established in their field or graduate students, are encouraged to enter the competition. Submissions from younger scholars are particularly welcomed. The essay should not exceed 8,00o words, including footnotes, and for this year should be submitted by 30 September. A judgement will be made at the end of November (the editors reserve the right not to award the prize if no essay of significant quality is submitted). The essay of the successful candidate will be published in the Journal, probably in the number appearing in July 2014. Other submissions entered into the competition may also be recommended for publication. All essays should be sent as two hard copies, prepared to journal style, to Mrs Anne Waites, Journal of Ecclesiastical History, Robinson College, Cambridge $\mathrm{CB}_{3}$ 9AN. 